\title{
HUMAN RIGHTS AND LAW ENFORCEMENT: THE USE OF FORCE IN COUNTER TERRORISM
}

\author{
${ }^{1}$ Tubagus Ami Prindani, ${ }^{2}$ Imam Subandi, ${ }^{3}$ Marthinus Hukom, ${ }^{4}$ Fayreizha Destika Putri \\ ${ }^{1}$ Sekolah Kajian Stratejik dan Global, Universitas Indonesia, tubagusamip@gmail.com \\ ${ }^{2}$ Faculty of Law, Universitas Diponegoro, Andymarshof@yahoo.com \\ ${ }^{3}$ Sekolah Tinggi Filsafat Driyarkara Jakarta, Marthinushk@gmail.com \\ ${ }^{4}$ Indonesia National Police Headquarters, fayreizhadp@gmail.com
}

\begin{abstract}
This paper aims at discussing the legal as well as the human rights impact on the use of force and firearms by law enforcement officers in the event of counter terrorism, case study of the Indonesian National Police Counter Terrorism Special Detachment 88 CT (Densus 88 AT Polri). The discussion focuses on the nature of the use of force as well as the use of lethal firearms by law enforcement officers made possible by international legislation and provisions on human rights. Is it possible that the use of force and lethal weapons is still in line with respecting and upholding human rights? How does the state's accountability in the event of use a force by law enforcement officers? How is the validity of the use of deadly forces in the event of arrest or raids conducted by police? Is it true that human rights are always contrary to police duties?
\end{abstract}

Keywords: Human Rights; Use of Force; Terrorism and Human Rights

\section{Introduction}

We often listen or watch news of the Indonesian police in this instance Densus 88 CT conducting arrests resulted in the death of the suspects or alleged terrorists. The news will soon be followed by numerous comments; some do not instantly blame the police but there are more who blame the police. With various reasons, they will immediately claim that what those police officers have done were not justifiable because in the context of law-abiding country, there is a principle of presumption of innocence. It means that everyone allegedly committing an offence or crime will be assumed innocent until proven otherwise by the Court. Therefore, it is only judge who has the right to decide if someone is guilty or innocent.

Like it or not, in law enforcement efforts involving the use of force, often death and serious injuries are unavoidable. However, if we pay close attention to those incidents, it is not only the suspects or terrorists who were killed or suffered from serious injuries but also the police officers. One of the incidents that still fresh in our mind is the hostage taking situation in Mobile Brigade Headquarter. ${ }^{2}$ This incident was started when the prisoners and inmates who haven't been transferred to the corrective facility attacked the police officers who guard the prison. At

\footnotetext{
1 A Jetschke, Human Rights and State Security: Indonesia and the Philippines. (Pennsylvania: University of Pennsylvania Press, 2011).

2 Bagus Prihantoro Nugroho, “36 Jam Kerusuhan Berdarah Di Mako Brimob,” Detik.
} 
that time instead of using firm actions, those police officers hid their weapons in the toilet and then negotiated the terms that resulted in those prisoners and inmates brutally attacked and killed the 6 police officers who were guarding the prison. ${ }^{3}$ Finally, 155 terrorist inmates including women and children took over the prison. ${ }^{4}$

The police officers, though fully armed and trained, were not dare taking firm actions because they were afraid of hurting women and children who were at the prison. They also completely understood the principle of 9 minutes golden moment, a moment or time that is important to take a decision to attack or paralyze an opponent or enemy, before the opponent or enemy can control the situation, in their SOP when taking over a turmoil; a principle that is applicable in various potential risks. They have made assessment to the possible incidents which likely to happen when having women and children in the prison along with 150 prisoners and inmates waiting for court verdicts dictating their transfer to other corrective facilities or prisons where some corrective facilities or prisons do not welcome them due to overcapacity while some others reject any terrorist inmates.

The death of those police officers has caused grievances to many people. However, many also think that death is a part of occupational risk of being a police officer and by its nature, police should realize that their job, especially in Densus $88 \mathrm{CT}$ is full of risks. Possibility of attacks committed by the prisoners and inmates against police officers should be understood and predicted prior to the incident so that they should have implemented "high security system" or "high alert system" in their prediction. On the other hand, when the Police implements the use of force such as conducting arrests or tactical measures against the terrorists, it may resulted in serious injuries or even death. Such incident would set a trigger for human rights observers in accusing and blaming the police for not acting professionally because their actions have made someone died or seriously injured. It is in contradictory to the fact that when police officers were killed, people would agree to this but when the alleged terrorists were killed, the Police in this regards, Densus $88 \mathrm{CT}$, are directly accused of not being professional. ${ }^{5}$ Therefore, we will use the case study of the attack at Mobile Brigade Headquarter for discussion based on the survey and qualitative research from the perspective of victims (officers who were tortured at the incident and survived), suspects' interviews, witnesses' testimonies (suspects or convicts who

Ibid.

M Rosseno and Rina Widiastuti Aji, "Drama 36 Jam Kerusuhan Di Rutan Mako Brimob,” Tempo.

A. J. Kusuma, "The Allegation of Human Rights Violation in the Process of Counter-Terrorism Acts in Indonesia by Densus 88 Force," Advanced Science Letters 24, no. 5 (2018): 3394-3398. 
witnessed the incidents but were disagree to the violence committed against the police). Due to immediate submission of this paper to be included in international journal, only some of the witnesses' and suspects' interviews and analysis were included as data in the discussion and to draw conclusion.

Siyono case, the case that drew the attention of Tim Pembela Muslim (literally means Moslem Defender Team, Yono's legal advisor), will be used as one of the references because what happened to Siyono has made the police officers who guarded him were sanctioned and formed as one of the factor for demotion (the transfer of employees from one position to another lower among organizations, so the authority, responsibility, income and status are also lower) and made the guarding officers in Mobile Brigade Headquarter were in doubt because they were afraid of being blamed by their supervisors when carrying out the use of force which inflicted injuries or death against the alleged terrorists and suspects. Although being sanctions, human rights observers still consider it a violation. Therefore, this paper is going to discuss the contrasting side of the issues which is lethality level of terrorism act using recent cases such as bombing attacks committed by a family comprises of father, mother and children against churches whom they believed not in line with their religion and belief, several cases in Sibolga and hostage taking in Mobile Brigade Headquarter as well as Siyono case as the data to analyse. On one side when a police officer or several police officers were badly injured or even died in their efforts of counter terrorism, it is considered as occupational risks but when the opposite happens, when suspects or alleged terrorists died as a result of police measures, it is considered as human right violations.

Not intending to give judgement to both perspectives and the constructing interests, this paper tries to analyse the situation based on national and international regulations. In this brief paper, from international principle in the use of force and firearms called "Basic Principle on the use of Force and Firearms" and national legislation Law number 5 in 2018 regarding the Eradication of Criminal Act of Terrorism. In the context of the use of force and firearms, Indonesia, in this regards, the Indonesian National Police (INP) has The Chief of INP Decree Number 8 of 2009 regarding the Implementation of Human Right Principles and Standards in the Discharge of Duties of the Indonesian National Police. Why does it matter? The Chief of INP Decree Number 8 of 2009 has had adopted several international provisions among others are "Code of Conduct for Law Enforcement Officials" and "Basic Principle on the use of Force and 
Firearms". ${ }^{6}$ This paper will be briefly and in general discuss the Chief of INP Decree Number 1 of 2009 regarding The Use of Force in The Context of Riot Control. This paper will also discuss Global Counter-Terrorism Strategy which sets the arrangement that at the end, counter terrorism must be in line with human rights. Therefore, this writing will focus on the following questions: (1) Is the use of lethal force and firearm still in line with the principle to respect and uphold human rights?; (2) How is the state's accountability in the use of force by law enforcement officers?; (3) How is the validity of the use of lethal force in the arrest or raid conducted by the police in counter terrorism?; (4) Is it right that human rights always contrary to police duties?

Those questions will initiate discussion as response to many people's opinion that when police conducted police measures resulted in deaths or serious injuries, they must have been violating human rights while when police officers are injured or even died on duty, they consider it as occupational risks. On the other hand, police feels that human rights are becoming obstacles in performing their duties or they even feel that human rights have treated the police unfairly. Some even wondering if police officers also have human rights and may claim it.

\section{Methods}

This study uses qualitative research from the perspective of victims (officers who were tortured at the incident and survived), suspects' interviews, witnesses' testimonies (suspects or convicts who witnessed the incidents but were disagree to the violence committed against the police). Due to immediate submission of this paper to be included in international journal, only some of the witnesses' and suspects' interviews and analysis were included as data in the discussion and to draw conclusion. Some of secondary material like the results of the the record of the hearings as well as the documents related with the topic were also exloited. Interview with respondents, informants werre also used, one among othres from police officers Detachment 88 CT, as well as from dossiers (BAP). Some related legal materials have also been compiled for further classification and systematization. The next step is to analyze all legal materials with a comparative approach, which is conducted by making comparisons. By comparing them, we can find clarities regarding a statutory provision in linne with the topic analysed. ${ }^{7}$ The data analysis process in this wrting is conducted by means of triangulation techniques. According to Sutopo

\footnotetext{
6 K Ramakrishna, "The Southeast Asian Approach" to Counter-Terrorism: Learning from Indonesia and Malaysia," Journal of Conflict Studies 25, no. 1 (2005).

7 Sudikno Mertokusumo, Penemuan Hukum Sebuah Pengantar (Yogyakarta: Cahaya Atma Pustaka, 2014).
} 
triangulation is the most commonly used method for increasing validity in qualitative research. In this case, what was examined through triangulation were perpetrators, witnesses and victims. ${ }^{8}$

\section{Results and Discussion}

\subsection{Is the use of lethal force and firearm still in line with the principle to respect and uphold human rights?}

The parameter and indicator of human rights violation are not based on if there are any injury or deaths during the use of force in law enforcement. To understand the relation between human rights and police use of force, we must refer to the principles and standards of international human rights namely Basic Principle on the Use of Force and Fire Arms adopted by the 8th UN Congress on the Prevention of Crime and Treatment of Offenders in Havana, Cuba, from 27 August to 7 September 1990 which then adopted by the INP in the Chief of INP Decree Number 8 of 2009 regarding the Implementation of Human Right Principles and Standards in the Discharge of Duties of the Indonesian National Police. ${ }^{9}$ The most important principle in relation to police use of force stated in the UN Basic Principle is in point: ${ }^{10}$

"Law enforcement officials shall not use firearms against persons except in self-defence or defence of others against the imminent threat of death or serious injury, to prevent the perpetration of a particularly serious crime involving grave threat to life, to arrest a person presenting such a danger and resisting their authority, or to prevent his or her escape, and only when less extreme means are insufficient to achieve these objectives. In any event, intentional lethal use of firearms may only be made when strictly unavoidable in order to protect life"

From the above point, there are at least 3 situations where police officers can use lethal force or firearms. They are, in a self-defence against imminent threat of death, in a defence of others against similar threat, and in preventing serious crime which resulting in death. Those three points should be used to assess if the suspect's death in police arrest or raid is a risk in law enforcement or human rights violation. Everyone must be honest in evaluating an incident. When a criminal gets injured or died as a result of police use of force, do not immediately accuse them of violating human rights because this will demotivate new INP officers on the field and make them afraid or in doubt taking firm actions. It may also increase the number of police officers killed in the line of duty. If INP officers are fallen because of feeling afraid and doubtful in

\footnotetext{
8 H.B. Sutopo, Metodologi Penelitian Kualitatif: Dasar Teori Dan Terapannya Dalam Penelitian (Surakarta: Universitas Sebelas Maret, 2006).

9 M. D. Kielsgard, "A Human Rights Approach to Counter-Terrorism," Cal. W. Int'l LJ 36 (2005): 249.

10 Ibid.
} 
taking actions, it is certainly that the State has bowed down and been defeated by criminals because police officers are representing the State and they are there to reflect the State's presence in protecting every citizen. Police failure is the State's failure. Police defeat is the State's defeat. If it happens, human rights protection is at stake!

This statement doesn't mean tolerating police "brutality"11 but firm actions in line with point 9 of the UN Basic Principles on The Use of Force and Firearms adopted in the Chief of INP Decree Number 8 of 2009 regarding the Implementation of Human Right Principles and Standards in the Discharge of Duties of the Indonesian National Police based on the principles of Legality, Necessity and Proportionality are not human rights violations. On December 17, 1979, the United Nations General Assembly passed Resolution 34/169, which stated that the functions of policing include maintaining public order functions and the manner in which public order functions are exercised have a direct effect on the quality of life of an individual, as well as society as a whole. The United Nations resolution emphasized that policing should provide the citizenry with protection of all human rights and human interests. The resolution also prescribes the Code of Conduct for the police officers of the world. Additionally, there are several other United Nations instruments ratified by the majority member States of the United Nations. They provide standards and norms for policing. These standards are known as international human rights standards. These instruments also contain the guidelines in regard to implementing the international human rights standards. Furthermore, they prescribe as to how to monitor abuse of human rights by the police as well as suggest suitable remedial measures, including punishment for violations. And when the code ethic court has found that those elements have been met, the Court should not be in doubt recommending that the police officer to be declared not guilty and to be reinstated.

Various parts of the UN have been responsible for resurrecting the human rights norm in this inhospitable era for three main reasons: the embeddedness of human rights in the UN's organizational structure; the role of the UNHCHR, which has over time become more visible and active within the UN agencies; and the presence of an outspoken proponent of human rights in the UN secretary-general. To increase the resonance of their arguments, UN human rights advocates make the twin points that, although terrorist actions themselves are a threat to human rights, human rights violations do also increase the population of terrorists. The CTC came under

11 S. Bandes, "Tracing the Pattern of No Pattern: Stories of Police Brutality," Loy. LAL Rev 34 (2000): 665. 
early pressure to be more assertive in assessing the human rights consequences of the reports that states make as part of obligations associated with Resolution 1373.

After several meetings, UN General Assembly Resolution 219, passed 18 December 2002, on respect for human rights and fundamental freedoms while combating terrorism, together with Security Council Resolution 1456 of 20 January 2003 on the same theme, declare that states should adopt only those antiterrorist measures that are in accordance with human rights, refugee, and humanitarian law. Annual UNCHR meetings in Geneva have considered reports of the UN special rapporteur on terrorism and human rights, which included a call to the CTC in the 2004 report to "fully incorporate human rights and humanitarian law obligations into its directives." The Office of the UNHCHR has produced the "Digest of Jurisprudence of the UN and Regional Organizations on the Protection of Human Rights While Countering Terrorism," which, among other matters, clarifies the concept of non-derogable rights under UN and regional human rights conventions. It states categorically, "This publication will help policy makers, including government officials, parliamentarians, judges, lawyers and human rights defenders, in developing counter-terrorism strategies that are fully respectful of human rights." No state can claim to be in ignorance. Similarly, the UN Committee Against Torture has been reminding state parties to the CAT of the non-derogable nature of the obligations they undertook in signing this convention. Nevertheless, the Office of the High Commissioner is under no illusions about the increased threats to virtually all human rights since September 2001, including threats to "human rights defenders . . . migrants, refugees and asylum-seekers, indigenous peoples and people fighting for their rights or against the negative effects of economic globalization policies. ${ }^{12}$

The General Assembly of the United Nations in 1979 adopted the Code of Conduct for Law Enforcement Officials (Res. 34/169, December 17). In this resolution, the General Assembly exhorts law enforcement agencies that possess police powers to respect and protect human dignity and maintain human rights. The General Assembly recommended that all United Nations members adopt the Code of Conduct for Law Enforcement Officials as a framework for legislation and/or as principles for police officers to practice. The potential for abuse by police officers was recognized by the General Assembly. Furthermore, the General Assembly strongly exhorted police officers to diligently uphold human rights. The Code of Conduct emphasized

12 David Capie, "Between a Hegemon and a Hard Place: The 4War on Terror' and Southeast Asian-US Relations," Pacific Review 17, no. 2 (2004): 239. 
that the use of torture be prohibited by police officers and that the use of physical force be used when absolutely necessary. ${ }^{13}$

\subsection{How is the state's accountability in the use of force by law enforcement officers?}

It should be started from the concept of Human Rights. In HRBA (Human Right Based Development Programming), the concept of Human Rights is the responsibility of every country as the "duty bearer" which means that they are holding the obligation towards the "rightsholders" or those holding rights. Therefore, the State in the context of human rights is the one implementing obligations and human rights. State has three responsibilities; "to fulfil", "to protect" and "to promote" or "to respect". Promoting and respecting human rights are for everyone to do, both the strong and the week. However, in the context of human right's protection, it is the State's responsibility. The State is equipped with organs and officers are paid by the State to act as its representative in fulfilling its duties: "to fulfil" and "to protect" and "to promote" or "to respect". ${ }^{14}$ Therefore, in the context of three state's duties, to protect is indeed the hardest. Why is it so? Because "to protect" must be strong so protecting everyone's human right is definitely the responsibility of the State. ${ }^{15}$

When the State is failed to protect or even resulted in the loss of someone's human rights, it is making sense if the State is accused of violating human rights. In the bottom line, when a State has "to fulfil" but is unable to perform, it still can be forgiven because fulfilling someone's human right is interrelated and even more when considering the State's capability. Fulfilment is usually strongly related to the State capability to provide means and infrastructures as well as economic capability to provide the needs of its citizens. In terms of "to respect", everyone is indeed able to do it because "to respect" is the lowest level by simply letting or tolerating others to exercise their human rights such as to embrace a religion. Therefore, letting others to exercise their religious activities is actually a form of respecting others' rights which is considered as the lowest level. If we cannot fulfil other's rights, at least we just let others to get their rights. "To protect" is definitely the State's obligation because it is related to the use of force. In human rights violation for example when there are people who express their freedom but their expressions of freedom tend or are likely to violate others' rights and it is impossible for the

13 S. Subramanian, Human Rights and Police. Hyderbaid (New Delhi: Association for Advancement of Police and Sciences, 1998).

14 D. J. Whittaker, Counter-Terrorism and Human Rights (London: Routledge, 2014).

15 Hans Peter and Kathryn Sikkink Schmitz, "International Human Rights," in Handbook of International Relations (London: SAGE, 2001).

16 Kielsgard, "A Human Rights Approach to Counter-Terrorism." 
week to protect their own rights when the strong violates their rights. It is where the State should be present. In this context, the use of force by law enforcement officers should be seen as the State representation or presence. Therefore, that is the time when the State is present and of course the State cannot do anything unless represented by its organs in the form of State apparatus. Police officers as the manifestation of the Police, when there is a terror incident, are representing the State. ${ }^{17}$ When the terrorists with their belief commit acts that they believe as the truth and expression of their freedom but at the same time, threaten other's right of living so the State should be present with the use of force in the form of law enforcement and when "soft approach" is not working, the last resort will be the use of force by the law enforcement officers. That's why injuries or death might happen when the police implements the use of force and there is no other options but using violence or force that may result in injuries or death. ${ }^{18}$ So, it must be understood that when police measures are legitimate, valid, reasonable and acceptable, those measures are not performed by someone or individuals who act on their own account but they present as the State.

Several important human rights issues that have been troubling people throughout the world are the use of excessive force and deadly force, primarily by the use of firearms. It seems that no country of the world is free from either the excessive use of force against people and/or the use of deadly force when it may be inappropriate or even illegal. To address the issue of excessive force and firearms by police officers, the Eighth United Nations Congress on Prevention of Crime and Treatment of Offenders passed the Basic Principles on the Use of Force and Firearms by Law Enforcement Officials in Havana, Cuba, in 1990. The Eighth Congress adopted these Principles which recommend that all states adopt and implement rules and regulations on the use of force and firearms by police officers. Furthermore, the ethical issues associated with the use of firearms should be kept constantly under review. Police officers should be equipped with the practical means for a differentiated use of force and firearms.

Additional recommendations include the development and deployment of nonlethal incapacitating weapons, the application of nonviolent means, and the provision of a reporting system whenever police officers use firearms in the performance of their duty. Police officers are especially exhorted to be sensitive in the use of force in dispersal of lawful and peaceful

17 J. Fitzpatrick, "Speaking Law to Power: The War against Terrorism and Human Rights," European Journal of International Law 14, no. 2 (2003): 241-264.

18 R. Foot, "The United Nations, Counter Terrorism, and Human Rights: Institutional Adaptation and Embedded Ideas," Human Rights Quarterly (2007): 489-514. 
assemblies. Such assemblies are recognized as part of a democratic way of life by the Universal Declaration of Human Rights in 1948. The use of force and firearms is considered so universally important that several other safeguards have been recommended, such as Proper screening procedures for law enforcement officials to ensure that they possess appropriate moral, psychological, and physical qualities (Article 18); Provision of training and testing to ensure appropriate proficiency standards in the use of force (Article 19); and Special attention to issues of police ethics and human rights, development of alternatives to the use of force and firearms, and the peaceful settlement of conflicts and understanding of crowd behavior (Article 20).

The preceding recommendations can be traced to the principles of Sir Robert Peel, who had training, ethics, and an unwillingness to arm the Metropolitan Police of London as a means of controlling the inappropriate use of firearms. In recent decades several publications have emphasized training along with appropriate moral, psychological, and physical characteristics. In adopting the Code of Conduct (Res. 179 34/169, December 17, 1979), the General Assembly of the United Nations stated that policing must be a "profession" and it is the duty of every profession to discipline itself. The world's police should be in complete conformity with the principles and standards provided in the Code of Conduct.

The United Nations urges that police officers should be responsive to public scrutiny. The standards upheld in the Code of Conduct will lack practical value unless the content and meaning - through education, training, and monitoring - become an integrated part of the creed of every police officer. The United Nations recommends that all governments should give consideration to incorporating the Code of Conduct. This should be done within the framework of national legislation or practice as a body of principles for observance by police officers. ${ }^{1920}$

The Code of Ethics for Law Enforcement prohibits corruption on the part of law enforcement officials regulated in Article 8. The code further emphasizes that police officers observe the following UN instruments religiously: Universal Declaration of Human Rights, 1948; International Covenant on Civil and Political Rights, 1966; Declaration on the Protection of All Persons from Torture and Other Cruel, Inhuman or Degrading Treatment or Punishment; United Nations Declaration on the Elimination of All Forms of Racial Discrimination; International Convention on the Persecution of Apartheid Crimes and Punishment; The Convention on the Prevention and Punishment of Genocide Crimes; Minimum Standards for the

19 M. J. Palmiotto, Police Misconduct: A Reader for the 21st Century (New York: Prentice Hall, 2001).

20 J. H. and J.F. Fyfe Skolnick, Above the Law: Police and the Excessive Use of Force (Canada: The Free Press, 1993). 
Treatment of Prisoners; and the Vienna Convention on Consular Relations (Article 2 [a]). Then In adopting the Code of Ethics (Res. 179 34/169, 17 December 1979), the General Assembly of the United Nations stated that the police must be a "profession" and it is the duty of every profession to discipline itself. The world police must really comply with the principles and standards given in the Code of Ethics.

\subsection{How is the validity of the use of lethal force in the arrest or raid conducted by the police in counter terrorism?}

We need to remember, as discussed in the introduction, that the nature of terrorism is deadly. If we take it lightly or think that the terrorists are just playing around or some consider that we are just exaggerating, don't forget horrible terrorism attack against the WTC building in New York known as Nine Eleven (9-11). ${ }^{21}$ Another terror attacks were also committed in several important locations in Mumbai; India Narima House (Ultra-Ortodox Jewish Building), Chabad Lubavitch; Leopold restaurant, Oberoi and Taj Mahal Palace and Tower Hotels ${ }^{22}$,Bali bombings and several other attacks. Those horrible attacks were beyond imagination. Hundreds or thousands of innocent people have become the victims, laid waste in the attacks which were claimed to be in the name of belief and religion. In fact, people whom we see wearing decent clothes, piously behaved and looked holy may act inhumanly because of their religion whom we think as a misconception but for them is a way of jihad so may result in death to the innocence only because the perpetrators have very strong belief and over fanaticism that makes them see the horrible act as their way to please their God and be granted heaven in return. ${ }^{23}$

The result of interviewing officers, from 2000 to 2016, there have been more than 100 police officers killed not to mention the incident in Mobile Brigade Headquarter that resulted in 5 officers killed. Data from Densus 88 CT shows that 1 police officer is killed for every 13 terrorism suspects killed during the use of force. Basic Principle on the use of Force and Firearms" has actually regulates 3 requirements namely legality, necessity and proportionality. ${ }^{24}$ In order to be legitimate, the following questions should be satisfied: do police acts have legal

21 A. Masferrer, "Post 9/11 and the State of Permanent Legal Emergency: Security and Human Rights in Countering Terrorism," Springer Science \& Business Media 14 (2012).

22 R. and S. Hashmi Puniyani, Mumbai: Post 26/11: An Alternate Perspective (New Delhi: SAGE Publications India., 2010).

23 C Gearty, “11 September 2001, Counter-terrorism, and the Human Rights Act,” Journal of Law and Society 32, no. 1 (2005): 18-33.

24 P Ruddock, “A New Framework: Counter-Terrorism and the Rule of Law," ThevSydney Papers 16, no. 2 (2004): 112. 
standing? Do police acts proportionate, which means that there is a balance between the threat plus likelihood of the incident to occur and police responses. Lastly, necessity principle which means that whether the police has to take action at that very moment or can it be delayed. This part is difficult to explain to the public because risk assessment is police subjectivity meaning that it is based on intelligence so besides legality given to the police officers, the police who uses force must know and able to answer several questions as indicator whether the use of lethal force should be immediately applied or not during the arrest and raid in terrorism case.

Legality questions like do I bring warrant, do I have authority, does the Law give me power to take actions and secondly is proportionality principle which means that the use of lethal force or firearms is proportionate to the level of threat. Is it enough for me to just use bare hand when dealing with a criminal or a terrorist or do I have to use riffle or pistol or baton. Of course this subjectivity can only be understood by the respective police officer. However, it is not something we cannot test. For example, after making the use of force, the officer will report to the supervisor. It is actually the time to review what the police has conducted and when the police has no more choice to make, it cannot be delayed any longer so here comes the necessity principle or immediateness of the act to be taken in response to the immediate threat. When police delays not to do an action while s/he believes that others or the police him or herself may be injured or killed, this the time for the police to decide to take action.

\subsection{Is it right that human rights always contrary to police duties?}

At glance, it seems right that human right is always opposing the police duties as explained before that the concept of human right is the protection of the citizens as mandated by international community to every country. If we look back to the history of human rights, they are the outcomes of human rights violation committed by the State to its citizen. So the concept of human rights is the concept of control exercised by international community to a country to force them not to violate the human rights of its citizen but to protect them. Therefore, it indeed seems that when police is being attacked, that is part of police duties and risks. It seems that way in a glance. When police officer is hit by someone or protester, society consider that it is normal because police duty is to deal with violence. On the other hand, when a member of society is hit by a police officer, it is human right violation. The same thing also when the member of society 
died. ${ }^{25}$ So, that is the reality. Because crime is not always in the form of human right violation as we understand. Even criminals in common type of crime can be charged with more severe penalty even death sentence. So from the perspective of the police, human right protection is in the form of legal protection, trainings and legal instruments equipped with all means and infrastructures as well as power and to some extent, weapon. Those are human right protections provided by the State to the police. So, once again, human right protection is in the form of trainings, infrastructures and equipment to perform their duties so that the police with their power should be able to assess and decide what actions must be taken to deal with certain situation. $^{26}$

The concept of human right as protection by the State, so when the State is failed and human rights violation takes place, the State is the one to be blamed. However, when the State's organ or apparatus in this instance is the police becomes the victim, it is understandable that it is considered as occupational risks and responsibilities. The form of protection is the punishment to the attacker. So when someone attacks an officer who are carrying out their duties, usually there is additional punishment as a form of protection to the police. In several countries, police is given protection in the form of welfare, health facilities, high salary and also insurance as well as trainings so that they could protect themselves because they act not as individuals but representing the State. ${ }^{27}$ By its nature, an arrest warrant is part of police's job and he or she has to use violence, the one using violence is the State not a person or individual. That is how the State come into present to protect its people by using all means and infrastructures reflected by the police who carry out their duties. So, it is the State who are performing the role as police officer when doing their duties.

When someone express their freedom, they should think that there are others' freedom that they should respect. However, they don't always realize others' freedom. They feel that themselves and their group's freedom are more important. It leaves no choice to the police. At the same time, the police have to act from soft actions, firm actions and hard actions to make them realize that they must respect others' rights. When taking firm actions, police sometimes are accused of taking the matter into their own hands and violating human rights. Here is the

25 S. Von Schorlemer, "Human Rights: Substantive and Institutional Implications of the War against Terrorism," European Journal of International Law 14, no. 2 (2003): 265-282.

26 Foot, "The United Nations, Counter Terrorism, and Human Rights: Institutional Adaptation and Embedded Ideas."

27 A. L. Smith, "A Glass Half Full: Indonesia-US Relations in the Age of Terror. Contemporary Southeast Asia,” $A$ Journal of International and Strategic Affairs 25, no. 3 (2003): 449-472. 
moment where it seems that the police is restrained by human rights. It is indeed what is right because police is very strong because they represent the State by having power, weapon, legal basis, quite high salary compared to the labors so they have to act in a high standard so that their claim of representing the State could be justified. ${ }^{28}$ Therefore, at glance it seems that human rights have always become obstacles to the police. As a matter of fact, when the police capable to do the job well in accordance with the procedures dictated by the Law, it means that the police act is the State act so when someone got injured or even died because of police acts, the injury or death is not because of police act but because of the State act. Therefore, the requirements should be really in accordance with the procedures so that the claim that the police representing the State is acceptable. ${ }^{29}$

\section{Conclusions}

The use of lethal force and firearms is still in line with the effort to respect and upholding human rights as long as international procedures and provisions have been adopted by the INP and implemented by police officers when facing unavoidable situation which requires the use of force and firearms. State's accountability in the use of force by law enforcement officers is by making sure that the use of force and firearms by the officers is the form of State's protection as the 'duty bearer' towards its citizens as the 'rights holder'. The use of lethal force during police arrest and raid in terrorism offence is acceptable if the law enforcement officers meet legality, necessity and proportionality principles. The notion saying that human rights is always against police duties seems valid because human rights regulate and put boundaries for the police not to do everything as it pleased. However, if the police do everything based on regulation, even if it is resulted in injuries or deaths to the suspects, it should be understood as a reflection of the State's presence in protecting the rights of its citizens. Therefore, it is necessary to provide education regarding Human Rights especially related to law enforcement to larger audience of the police and general public and in a more intensive forum or events.

28 M. Taufiqurrohman, "Counterterrorism in Indonesia," Counter Terrorist Trends and Analyses 5, no. 6 (2013): 710.

29 H. Tegnan, "Designing a Counter-Terrorism Legal Policy Complying with Human Rights and Democracy in Indonesia," Journal of Legal, Ethical and Regulatory Issues 21, no. 2 (2018): 1-7. 


\section{References}

Aji, M Rosseno and Rina Widiastuti. "Drama 36 Jam Kerusuhan Di Rutan Mako Brimob." Teтpo.

Bandes, S. "Tracing the Pattern of No Pattern: Stories of Police Brutality." Loy. LAL Rev 34 (2000): 665 .

Capie, David. "Between a Hegemon and a Hard Place: The 4War on Terror' and Southeast Asian-US Relations." Pacific Review 17, no. 2 (2004): 239.

Fitzpatrick, J. "Speaking Law to Power: The War against Terrorism and Human Rights." European Journal of International Law 14, no. 2 (2003): 241-264.

Foot, R. "The United Nations, Counter Terrorism, and Human Rights: Institutional Adaptation and Embedded Ideas." Human Rights Quarterly (2007): 489-514.

Gearty, C. "11 September 2001, Counter-terrorism, and the Human Rights Act." Journal of Law and Society 32, no. 1 (2005): 18-33.

Janzekovic, J. The Use of Force in Humanitarian Intervention: Morality and Practicalities. Routledge, 2017.

Jetschke, A. Human Rights and State Security: Indonesia and the Philippines. Pennsylvania: University of Pennsylvania Press, 2011.

Kielsgard, M. D. “A Human Rights Approach to Counter-Terrorism.” Cal. W. Int'l LJ 36 (2005): 249.

Kusuma, A. J. "The Allegation of Human Rights Violation in the Process of Counter-Terrorism Acts in Indonesia by Densus 88 Force.” Advanced Science Letters 24, no. 5 (2018): 3394 3398.

Masferrer, A. "Post 9/11 and the State of Permanent Legal Emergency: Security and Human Rights in Countering Terrorism.” Springer Science \& Business Media 14 (2012).

Mertokusumo, Sudikno. Penemuan Hukum Sebuah Pengantar. Yogyakarta: Cahaya Atma Pustaka, 2014.

Nugroho, Bagus Prihantoro. “36 Jam Kerusuhan Berdarah Di Mako Brimob.” Detik.

Palmiotto, M. J. Police Misconduct: A Reader for the 21st Century. New York: Prentice Hall, 2001.

Puniyani, R. and S. Hashmi. Mumbai: Post 26/11: An Alternate Perspective. New Delhi: SAGE Publications India., 2010.

Ramakrishna, K. "The Southeast Asian Approach" to Counter-Terrorism: Learning from 
Indonesia and Malaysia." Journal of Conflict Studies 25, no. 1 (2005).

Ruddock, P. "A New Framework: Counter-Terrorism and the Rule of Law." ThevSydney Papers 16, no. 2 (2004): 112.

Schmitz, Hans Peter and Kathryn Sikkink. "International Human Rights.” In Handbook of International Relations. London: SAGE, 2001.

Von Schorlemer, S. "Human Rights: Substantive and Institutional Implications of the War against Terrorism.” European Journal of International Law 14, no. 2 (2003): 265-282.

Skolnick, J. H. and J.F. Fyfe. Above the Law: Police and the Excessive Use of Force. Canada: The Free Press, 1993.

Smith, A. L. "A Glass Half Full: Indonesia-US Relations in the Age of Terror. Contemporary Southeast Asia." A Journal of International and Strategic Affairs 25, no. 3 (2003): 449472.

Subramanian, S. Human Rights and Police. Hyderbaid. New Delhi: Association for Advancement of Police and Sciences, 1998.

Sutopo, H.B. Metodologi Penelitian Kualitatif: Dasar Teori Dan Terapannya Dalam Penelitian. Surakarta: Universitas Sebelas Maret, 2006.

Taufiqurrohman, M. "Counterterrorism in Indonesia." Counter Terrorist Trends and Analyses 5, no. 6 (2013): 7-10.

Tegnan, H. "Designing a Counter-Terrorism Legal Policy Complying with Human Rights and Democracy in Indonesia." Journal of Legal, Ethical and Regulatory Issues 21, no. 2 (2018): 1-7.

Whittaker, D. J. Counter-Terrorism and Human Rights. London: Routledge, 2014. 